\title{
A "Privileged Partnership?" Franco-German Relations and the Development of EU Social Policy
}

\author{
Michael G. Huelshoff, University of New Orleans
}

The revival of European Union studies has, to date, been guided primarily by intergovernmental theories of regional integration. This essay examines one intergovernmental model of regional integration, namely coalition building between France and Germany. In a case study of EU social policy, it is found that the trajectory of policy-making is not consistent with the predictions of the coalition version of intergovernmentalism. Rather, models of regional integration should pay more attention to the domestic politics of members to better explain their behavior at the European level.

The "recasting" (Sandholtz and Zysman 1989) of the European Union (EU) embodied in the Single European Act (SEA) and the Maastricht treaty revisions has re-ignited the study of regional integration. ${ }^{1}$ As the EU seemed to stagnate after the early 1970 s, academics shifted their focus from regional to international interdependence (Keohane and Nye 1977; Haas 1975). Now, the pendulum has swung back. A small cottage industry has developed to explain the SEA itself (Sandholtz and Zysman 1989; Moravcsik 1991; Tranholm-Mikkelsen 1991; Cameron 1992; Garrett 1992), relying upon a re-introduction of one of the two dominant models of regional integration (or, as in Cameron's case, a melding of the two), either neo-functionalism or intergovernmentalism. Clearly, the intergovernmental argument has received the most attention.

I have argued elsewhere $(1991-92 ; 1993 ; 1994)$ that the re-introduction of elements of neo-functionalism does not expand our understanding of regional integration, and adds dangerously deterministic elements to the models. I have also suggested that intergovernmental models of regional integration that emphasize state-centric actors fail to explain a significant share of the variance in outcomes in EU policy-making. In this essay, I examine another form of the intergovernmental model, namely coalition building among the major state actors (Simonian 1985; Wallace 1985, 1986).

Simply put, this model of regional integration assumes, like the other version of the intergovernmental argument, that states can be treated as single, unitary actors. Member states are said to seek to dominate the EU

Michael G. Huelshoff is Associate Professor of Political Science, University of New Orleans.

The American Review of Politics, Vol. 16, Fall, 1995: 253-276

๑1995 The American Review of Politics 
policy agenda to maximize their national interests. Yet the combination of oting rules and the political culture of the EU (the emphasis upon consensus, present even under qualified majority voting rules) prevent any single state from achieving a dominant position, and hence states must build coalitions among themselves. For a variety of historical, political, and economic reasons, the most active, enduring, and successful of these coalitions is said to have been the Franco-German coalition. It is argued that the close political ties between France and Germany, as epitomized by the frequent FrancoGerman summits, permit the two to fashion joint positions on EU issues. Due to the power (political and economic) and leadership capabilities of the two states, it is argued that the jointly-determined policy preferences of the French and Germans come to dominate the EU agenda and (often) policy outcomes. Hence, regional integration can be understood as the outcome of Franco-German coalition building. This essay tests the hypothesis that coalition building between France and Germany provides the policy proposals and leadership necessary to the passage of EU legislation. If true, this hypothesis would predict that EU policy will reflect closely the collectivelydetermined interests of the French and Germans.

To test this hypothesis, this paper analyzes Franco-German cooperation in the development of social policy in the EU. It is found that, despite the much-publicized summits between French and German heads of government, the French and Germans have yet to develop close inter-ministerial contacts, and to attempt to coordinate policy initiatives, in the area of social policy. Indeed, in the case of the European Charter of Fundamental Social Rights, short-term political considerations led to friction between the French and Germans. Further, linguistic constraints, domestic political arrangements, and the problem-solving nature of the coalition-building process in the EU have led the Germans to develop closer contacts with northern European states, at the expense of Franco-German relations. This is not to suggest that Franco-German relations have been weakened by these shortcomings and complexities. Rather, in social policy Franco-German relations are relatively underdeveloped, and significant barriers to cooperation may hinder the development of joint positions. This paper will explore these barriers, many of which are found at the domestic level. A more general treatment of the domestic determinants of national policy preferences in the EU can be found in Moravcsik (1993) and Huelshoff (1994). These findings suggest another explanation for the recurrent misunderstandings between Paris and Bonn, including the French confusion over German unification, the failure of both governments to negotiate a solution to the currency crisis of 1993, and most recently the conflict over the Lamers report on institutional reform in Europe. 
The paper is divided into four sections. The first section briefly explores methodological questions. Second, the relative status of social policies and conditions in Europe are briefly reviewed. The third section examines the politics of social policy in the 1992 program. The development and implementation of the European Social Charter will be examined, to demonstrate the difficulties in working out joint Franco-German positions on social issues. Finally, the paper will examine the implications for integration theory of these findings.

\section{Methodological and Data Considerations}

On the surface, the problem of coalition formation in the EU would seem to be a natural place to apply the many and detailed lessons of coalition theory. Questions of coalition building have received much attention in political science, and our understanding of coalition building and behavior is highly sophisticated. Yet the unavailability of EU voting records makes it very difficult to test hypotheses drawn from this literature. Quite simply, the Council of Ministers, the EU body which votes upon policy proposals emanating from the European Commission, has refused until very recently to publicize its voting record. ${ }^{2}$ The Council has allowed public access to some parts of its meetings, but the initial press reports suggested that governments continued to avoid public discussion of their bargaining positions.

Even with these data, reliability questions remain. The Council is allowed to re-draft Commission proposals, although the Commission must approve these revisions. Thus, controversial issues often result in significant re-drafting of Commission proposals. The very nature of what is voted upon, then, is subject to negotiation. In the context of the Luxembourg Compromise, which allows members to veto legislation deemed counter to their national interest, states avoid isolating each other in the Council (Nugent 1992). The emphasis placed upon consensus, even under qualified majority voting rules, in the context of the prospects for re-working controversial legislation, leads to broad compromises with few winners and losers. Even with voting data, critical information is lost. ${ }^{3}$

Therefore, this essay relies upon case study methods to explore the strength and significance of the Franco-German alliance. This is not the place to recap the debates about small- versus large-n methodologies. These data are offered in the spirit of an Eckstein plausibility probe, with the recognition that this study alone cannot reach closure on the question at hand. Regardless, at the least these data suggest the need for caution in approaching models of EU policy-making that rest upon the Franco-German 
coalition, and hence the case furthers our understanding of EU policymaking.

The case of EU social policy was chosen because the near completion of the internal market has increased the political salience of social policy in the EU. As many of the remaining barriers to trade have been eliminated, national differences in social policy have been increasingly seen as potential distortions to trade. Commission President Delors, for example, named social and environmental policy as key flanking policies to the internal market. Additionally, the Maastricht Treaty moved social policy from unanimity to qualified majority voting rules, to expedite its harmonization. Social policy also significantly broadens the set of interests and interest groups that find themselves at the apex of policy-making. That is, as the internal market is realized, and the EU turns to social policy, new groups find their interests rising on the agenda, and a broader range of the public is even more directly affected by EU policies. Therefore, social policy is a key element of the internal market, receiving more attention from elites, and a politically salient area in the minds of a broad range of the public.

\section{Social Conditions in Europe and the Weakness of EU Social Policy}

Table 1 presents data analyzing employment programs among EU members. While all enjoy firmly grounded unemployment programs, differences exist among the states as regards eligibility, length and breadth of support, and other provisions. More significant differences exist in employment-related programs. Only Germany, Italy, Luxembourg, and the Netherlands provide financial support for workers reduced to part-time employment, only Germany, Belgium, Denmark, Italy, and Luxembourg provide funds for workers who miss work due to inclement weather, only the Germans provide assistance for seasonally-dependent workers (especially construction $)^{4}$ and only Greece and the Netherlands provide no public assistance for early retirement. Among the remaining ten members with such programs, differences over coverage, eligibility, and financial assistance are common. Finally, only Germany provides regular retraining funds for workers and release time for parents, and only Germany, France, Greece, and the Netherlands provide the possibility for workers to return to their positions after illness, pregnancy, and other reasons for absence.

Differences in income and hours worked per year are also significant (Table 2). The average Portuguese worker earns about a fourth what the average Luxembourger earns, and must work an additional 233 hours a year to do so. While the differences among most Northern European states are not as great as this, it still takes the average French worker 70 hours more 


\section{Table 1. Comparison of Work-Related Social Policies in the EU}

1. Unemployment Programs
a. Qualification requirements
b. Employment assistance for workers and business
c. Assistance for self-employment
d. Work-proving mechanisms (public employment schemes)

2. Employment Programs
a. Qualification requirements
b. Financial assistance for part-time work
c. Financial assistance for workers during poor weather periods
d. Assistance for seasonal workers
e. Early retirement provisions: -provisions for reduced hours for older workers - provisions for reduced pay for semi-retired workers

\section{Other Programs}

a. Educational assistance/provisions for child care leave

b. Provisions for returning to work (after pregnancy, etc.)
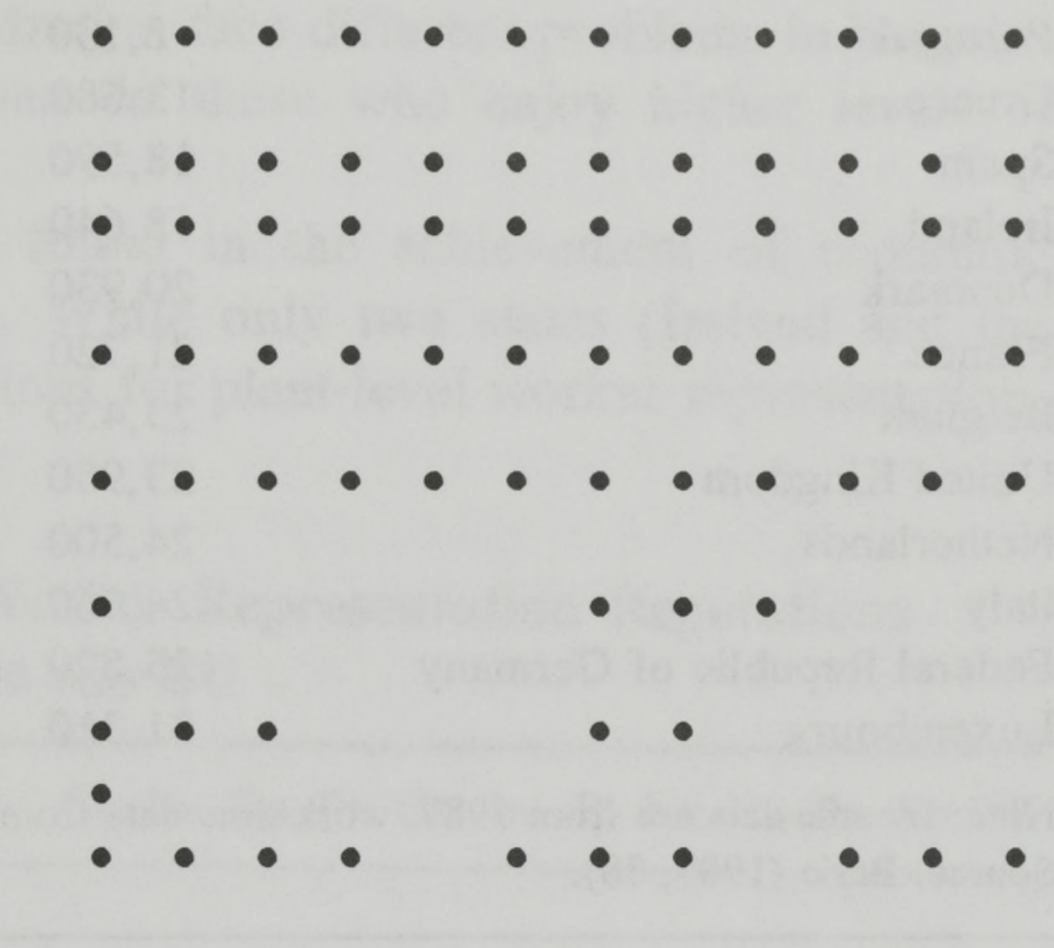

Source: BAS $(1989,121)$.

per year to earn about 15 percent less than his or her German counterpart. Potential harmonization of EU social policies is complicated not just by the severity of current differences in policy. The large variance in the political organization of the domestic participants in social policy-making, capital and labor, also hampers European-level coordination (Table 3). Only about 10 percent of all French workers are organized in unions, and these unions are politically divided. In contrast, German unions organize about 41 percent of the work force, and enjoy a close relationship with the state via the Deutscher Gewerkschaftsbund (DGB). Data on business organization are less reliable and difficult to assess, but Table 3 suggests that business associations in France and Germany represent business to comparatively similar degrees, while business associations in the United Kingdom and Italy (with 
Table 2. Average Net Income and Work Time in the EU

\begin{tabular}{lcc}
\hline & $\begin{array}{c}\text { Net Yearly Income } \\
\text { (in DM) }\end{array}$ & $\begin{array}{c}\text { Hours Per Year } \\
\text { Spent Working }\end{array}$ \\
\hline Portugal & 8,130 & 2025 \\
Greece & 13,680 & 1840 \\
Spain & 18,590 & 1800 \\
Ireland & 18,640 & 1864 \\
Denmark & 20,930 & 1733 \\
France & 21,720 & 1767 \\
Belgium & 23,430 & 1748 \\
United Kingdom & 23,950 & 1778 \\
Netherlands & 24,500 & 1756 \\
Italy & 24,960 & 1768 \\
Federal Republic of Germany & 25,820 & 1697 \\
Luxembourg & 31,310 & 1792 \\
Note: Income data are from 1987, work time date from 1988. & \\
Source: Berie (1989, 38). & & \\
\hline
\end{tabular}

Table 3. Organization of Workers and Business in the EU

\begin{tabular}{lrr}
\hline & $\begin{array}{c}\text { Percent of Workforce } \\
\text { Who are Members } \\
\text { of Unions }\end{array}$ & $\begin{array}{c}\text { Number of Firms } \\
\text { Which are Members } \\
\text { of Employer Unions }\end{array}$ \\
\hline Federal Republic of Germany & 41 & $1,200,000$ \\
Netherlands & 29 & 8,000 \\
United Kingdom & 48 & 200,000 \\
Ireland & 45 & 3,500 \\
Belgium & 75 & 30,000 \\
Portugal & - & 35,700 \\
Luxembourg & - & 250 \\
Greece & $8-14$ (est.) & 2,500 \\
Spain & 47 & $1,200,000$ \\
Italy & 10 (est.) & $1,000,000$ \\
France & 86 & 22,000 \\
Denmark & & \\
Note: Data on the percentage of firms belonging to employer associations is unavailable. & \\
Source: BAS (1989, 74-5). & &
\end{tabular}


economies of similar size) represent comparatively few firms. What these data can not assess, of course, is the relative political significance of these organizations. In both Germany and France, business associations have close relationships with the state. Those states which enjoy relatively low levels of employer and employee organization face different problems in bargaining common social standards than do those who enjoy higher levels of organization. $^{5}$

Great differences are also found in the achievement of economic democracy in Europe (Table 4). While only two states (Ireland and the United Kingdom) have no provisions for plant-level worker representation,

\section{Table 4. Comparison of Worker Representation Regulations in the $\mathbf{E U}$}

1. Plant-Level Representation
a. Membership
-Elected by all employees
-Mixed worker/management rep.
-Mixed system
b. Powers
-Access to information
- Consultation over closures
-Consultation over social iss.
-Consultation over investment
-Mediation of disputes poss.
-Decision-making powers

2. Company-level Representation
a. Parity Codetermination
b. Codetermination w/o parity
c. Labor rep. possible, but not required by law
d. No overall regulations, but codetermination not ruled out
e. No regulations

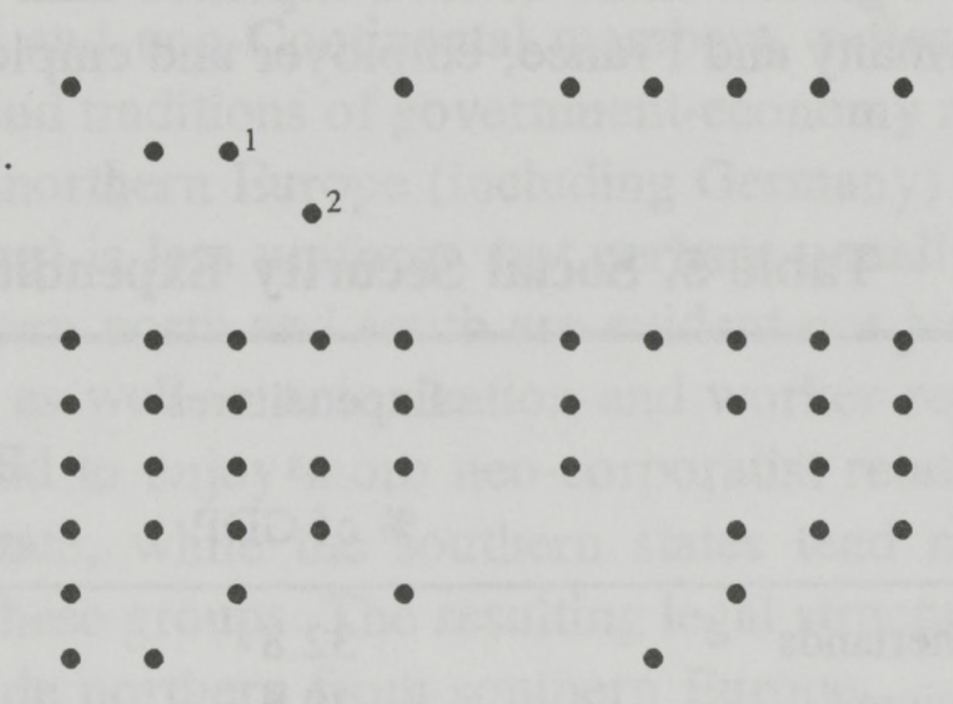

Notes: ${ }^{1}$ Recommended, but not required by law. ${ }^{2}$ Three organizational forms are specified by law, including a personnel delegation, made up of 11 worker representatives, a works council, made up of representatives elected by workers and management, and a union representation, made up union representatives. ${ }^{3}$ Only in coal and steel industries. ${ }^{4}$ Most other firms. ${ }^{5}$ Some codetermination without parity in some or all public enterprises and/or administration.

Source: BAS (1989, 76-80). Author's calculations. 
differences among European states concerning consultations over closures, investment, and social issues are common. Yet only Germany, Denmark, Greece, and the Netherlands include in their legislation provisions for the resolution of disputes, and only Germany, Luxembourg, and Belgium provide for some sharing of power between works councils and management. Codetermination at the firm level is even more diverse. True parity codetermination exists only in the German coal and steel industries, and only four states allow for even "weak" codetermination. The others do not necessarily rule out "weak" codetermination, but it tends to be very uncommon.

Finally, Table 5 shows that there are considerable differences among European states concerning social security expenditures and financing. At the high end, the Dutch spend about a third of GDP on social security, compared to only 15.2 percent for the Portuguese. Germany and France, though, spend about the same amount of GDP, but differ in its financing. The German government spends significantly more for social security than does the French state, and French business spends considerably more than German business to finance social security programs. German workers also pay a greater share of such expenses than their French counterparts. In both Germany and France, employer and employee contributions lie significantly

Table 5. Social Security Expenditures and Financing, 1984

\begin{tabular}{lcrrrr} 
& $\begin{array}{c}\text { Expenditures } \\
\text { as }\end{array}$ & \multicolumn{4}{c}{ \% Financed by } \\
& \% of GDP & $\begin{array}{c}\text { Employ- } \\
\text { ers }\end{array}$ & ees & $\begin{array}{c}\text { Ement } \\
\text { ment }\end{array}$ & Other \\
\hline Netherlands & 32.8 & 31.9 & 36.3 & 17.7 & 14.1 \\
Belgium & 29.6 & 41.4 & 19.7 & 33.8 & 5.2 \\
France & 29.4 & 51.9 & 24.5 & 20.2 & 3.4 \\
Denmark & 28.9 & 10.2 & 3.8 & 78.8 & 7.2 \\
Federal Republic & 28.5 & 41.2 & 30.0 & 25.3 & 3.5 \\
Italy & 27.3 & 53.1 & 14.6 & 30.7 & 1.6 \\
Luxembourg & 25.2 & 33.7 & 25.8 & 32.2 & 8.3 \\
United Kingdom & 24.6 & 30.4 & 16.7 & 43.2 & 9.0 \\
Ireland & 23.9 & 21.6 & 11.7 & 65.9 & 0.8 \\
Greece & 20.0 & 23.0 & 23.9 & 49.0 & 4.2 \\
Spain & 17.4 & 53.2 & 19.9 & 25.8 & 1.0 \\
Portugal & 15.2 & 47.1 & 17.3 & 33.1 & 2.5 \\
Unweighted EU Average & 25.2 & 36.6 & 20.4 & 38.0 & 5.1 \\
Source: Mosley (1990, 158-59). & & & & & \\
\hline
\end{tabular}


above EU averages, and the governmental contribution is below the EU average. Clearly, any adjustment to a common EU level would require political adjustments in both France and Germany that can be expected to be quite contentious.

Across the EU, the differences among states are even greater than those between France and Germany. Employers pay the largest percentage of social security in Spain, just slightly more than do employers in France. The Netherlands requires employees to pay the largest share (over a third), and the Danish government pays the largest share among European states. Again, EU-wide compromises (necessary to ensure not only common social standards for all workers but to eliminate indirect barriers to investment) would require politically sensitive adjustments among most members.

Tables 1-5 demonstrate the breadth of differences in social policy among EU members. While all enjoy unemployment programs, they differ significantly in the extent to which government intervenes in labor markets, in terms of employee training, representation, non-wage compensation, provision and financing of social security, and levels of employee and employer organization. These differences follow roughly two patterns. First, there is a clear split between Continental and non-Continental members, reflecting differing economic philosophies and traditions of government-economy relations. The second split, between northern Europe (including Germany) and southern Europe (including France) is less uniform, but perhaps equally as significant. The differences between north and south are evident not just in income, but manifest themselves as well in unionization and worker representation. The northern states tend to enjoy more neo-corporatist relations among capital, labor, and the state, while the southern states tend more toward pluralist relations among these groups. The resulting legal structures, as represented in these data, divide northern from southern Europe.

It is not surprising that there are such great differences in social organization and legal order among states with such wide varieties of historical experience and levels of development. What is surprising is that, after more than 35 years of close association through the EU, these differences in social policy remain so acute. In the negotiations before the signing of the Treaties of Rome, a social dimension to the EU was debated, largely at the insistence of the French delegation, but existing differences among states were so great that a specific social role for the EU was rejected (Mosley 1990, 149-50).

As a result, the Treaties of Rome included only a few provisions relating to social affairs. ${ }^{6}$ The only institutional element was the European Social Fund, which provides financial assistance for vocational retraining or resettlement, and income support for workers temporarily laid-off or working part-time (Laffan 1983). The few social provisions of the Rome treaties 
were intended to ease the functioning of an otherwise liberal market throughout Europe, and not to protect or enhance the rights of workers. Many EU members anticipated a growth in common social policy after 1958. Additionally, social issues and problems were not seen to be as acute as they would become with the return of regular bouts of recession and inflation, beginning about a decade after the signing of the Treaties (Venturini 1988, 16).

The stagflation of the 1970 s led to renewed efforts to strengthen the EU's social dimension, to little effect. The Paris Summit of 1972 attempted to address social issues by calling for the establishment of the European Regional Development Fund and the Social Policy Action Programme, the latter of which was established in 1974 by Council directive. It is viewed as only a partial success. While progress was made in such areas as sex discrimination in employment, advanced notice of large-scale layoffs, rights of workers during business buy-outs, worker rights during bankruptcy, and occupational health and safety (Mosley 1990, 150-53), little progress was made in most other areas, including the balance of the economic democracy program. Institutional reforms, to include corporatist-style tripartite consultation in Commission and Council procedures, were also attempted with mixed success (Venturini 1988, 21-25). During the 1970s and 1980s, breakdowns in consultation among capital, labor, and the EU occurred throughout the regular meetings of the Standing Committee on Employment, and most notably when the Vredeling Directive was tabled in 1986. Overall, EU social policy until the signing of the Single European Act (SEA) was uneven, highly controversial, and subject to significant political influence by member states. By 1985, European social policy could be said to be virtually non-existent, with the notable exceptions of sex discrimination, protection of migrant workers, and some limited provisions in labor law. Even these areas, especially the sex discrimination laws, suffered from incomplete implementation among members, a problem that afflicts a wide range of $\mathrm{EU}$ law.

The aim of existing EU social policy is to guarantee freedom of movement for workers, to eliminate competitive distortions in the European market caused by differences in social policy, to reduce the social costs of market processes (notification of large-scale layoffs, etc.), and to reduce the costs of restructuring brought on by EU policy in industries such as coal and steel, textiles, and agriculture (Mayer 1989, 348). European social policy, then, is primarily designed to ease the functioning of market mechanisms, and even in this role it has been only a partial success. Progress in broader areas such as coordination of laws falling in the area of economic democracy has been very limited. Even in those areas which were clearly market- 
oriented, the economic instability of the 1970s and first half of the 1980s, disagreements among members over how best to address economic instability, the problems of integrating new members into the $\mathrm{EU}^{7}$ and unanimity voting rules in the Council have limited progress toward common social policies in the EU. The result, as we see in Tables $1-5$, is widely varying social programs among members, and, with the SEA, heightened concern about the implications of these differences in a truly common market after 1992.

\section{Franco-German Relations, Social Policy, and the SEA}

There were few provisions in the SEA for the development of social policy. Binding provisions included the approximation of national regulations regarding health, safety, and consumer and environmental protection. The creation of processes of cooperative decision-making (some form of codetermination) is mentioned in Article $118 \mathrm{~b}$, but this provision is nonbinding. Indeed, the lack of attention to social policy, and the impression that 1992 would benefit business alone, generated political conflict both in the EU and in many of the member states.

The European Trade Union Confederation (ETUC), whose members include both EU and non-EU trade unions, was the focal point of labor displeasure with the SEA. It protested the lack of a social dimension in the original proposals to complete the internal market in 1985 (ETUC $1985 \mathrm{a}, \mathrm{b}, \mathrm{c}, \mathrm{d})$, and, while supporting the ratification of the SEA in 1987, also continued to push for the inclusion of social policy (ETUC 1987a,b; 1988). The concerns raised by the ETUC, and by many unionists, focused upon the likelihood of "social dumping" after completion of the internal market. Social dumping includes three related processes: the displacement of highcost and -wage producers by low-cost and -wage producers when European markets are opened, the potential for firms in high-cost and -wage countries to relocate once markets are opened (or at least to pressure workers to reduce wages to avoid relocation), and the use by states of low-wage and anti-union policies to catch up to competitors (Mosley 1990, 160). While factors such as infrastructure, a skilled work force, and location offset the significance of social dumping, it was feared that social dumping could occur in specific industries, particularly labor-intensive sectors or in industries where other costs (such as those imposed by high environmental standards) are high. Other fears raised by 1992 include a strengthening of the existing division of labor (and income) in Europe (the opposite of social dumping), the likelihood of social migration to high-benefit countries (Mayer 1989, 355-56), and a weakening of national policies under the 
pressures a more open market, including health and safety standards and worker representation (Muhr 1990, 5).

The arguments about social dumping are highly political. In at least one case, controversy over social dumping has led to significant inter-state conflict in the EU. In the spring of 1993, Hoover Corporation announced the closure of one of its manufacturing facilities in France, shifting production to an expanded Scottish facility. This came after the Scottish government offered Hoover investment incentives. Hoover itself also cited lower indirect labor costs-the costs, in other words, of comparatively (to Scotland) stringent French social laws-as a reason for the move. Both the French government and EU President Delors labelled Hoover's decision social dumping, and vigorously but unsuccessfully campaigned for its reversal.

Social dumping is a myth in the minds of the European-level business lobby. The Union of Industries of the European Community (UNICE) supports a liberal vision of the internal market, and views social issues as important but secondary to its completion (Tyszkiewicz 1989). German and French business associations express similar doubt about the likelihood of significant social dumping (BDA 1989).

The SEA, then, did not address social policy issues directly, and as a result has re-ignited the debate about the EU's social deficit. After ratification of the SEA in 1987, and under pressure from the ETUC, national trade unions including in particular the DGB, and the French government, the Commission proposed in 1988 a significant strengthening of EU social policy, especially the adoption of a European Social Charter (Commission of the EU 1988a, 1988b). A non-binding version of the Social Charter was approved by eleven EU members (excluding the United Kingdom) in December 1989 (Council of the EU 1989). While an implementation program was proposed by the Germans, it failed to move the Social Charter from proposal to policy. To analyze these developments the apparatus for Franco-German cooperation is examined. It will be shown that there is little cooperation between the two for a variety of reasons. The two states disagreed over the Charter. An explanation of the failure of the Franco-German hypothesis to explain this outcome requires the relaxation of the state-centric assumption of intergovernmentalism. The implications of these factors are then explored in the politics leading to and following adoption of the European Social Charter. 


\section{The Franco-German Coalition and the Social Charter}

The EU's Charter of Fundamental Social Rights has its roots in the Council of Europe's Social Charter, adopted in 1960 and ratified by nine EU members (ETUC 1988, 5). France and Germany supported in general proposals to strengthen EU social policy as they worked their way through the Val Duchesse negotiations between the Commission, the ETUC, and UNICE. They also supported the EU Economic and Social Committee's proposals (the Beretta Report), and initiatives in the European Parliament. Yet there is little indication of policy coordination between the French and German governments at these preliminary stages. This lack of coordination continued after the Commission proposed the Charter in 1988. I explore here first the general policy context, and then the relations between the French and the Germans during the negotiations over the Charter. ${ }^{8}$

Officials in the German Ministry for Labor and Social Affairs report no particularly close relationship with their French counterparts. Rather, they suggest that they meet approximately twice as often with their British colleagues, and have closer relations with other (as they describe it) northern European states than with France (including Ireland, Denmark, and the Netherlands). Several explanations are offered. First, social policy initiatives remain underdeveloped in the EU, and hence there is little pressure for cooperation with other states including the French. When issues arise, German policy makers indicate that the closest coordination occurs with the government then holding the presidency of the European Council. Additionally, many of the northern European countries (excluding Ireland and the UK) enjoy similar political, administrative, and legal structures, enhancing cooperation among them. The Benelux countries and the FRG also find it easier to cooperate as they are all led by conservative governments. Language difficulties are also reported to hinder Franco-German cooperation. Among the northern European states English is a common second language, but not in France. This helps to further policy coordination among the northern European states, at the expense of the French, in the minds of German policy-makers at the ministerial level. Finally, there is a tendency for contacts to develop, from the German point of view, most intensely with those states most opposed to European-level social policies, namely the British. Policy coordination may be less important between the French and the Germans in the area of social policy because the greatest differences of opinion, on some issues, are found between the Germans and the British.

Additionally, there are signs that differences in French and German views of the economy and government-economy relations continue to diverge. The German view of the EU is consistent with German post-war 
economic philosophy which emphasized free markets, a philosophy which while not always translated into practice, has grown in importance during the past decade of center-right government in Germany (Reich 1990). The French tradition is quite different. French approaches to the economy have traditionally rested much more heavily upon management of capitalism than have German approaches. While the French began in the mid-1980s to move toward the German position, they remain far apart. The recent German initiative to create an independent body to vet existing and new EU laws to eliminate unnecessary, overly complicated, and inappropriate regulations has been ignored by Paris. At the Franco-German summit in May of 1994, the French government refused to commit itself to a jointly-sponsored report calling for reductions in labor market regulations, linkages between pay and productivity, and lower trade barriers to cheap imports to improve competitiveness and cut unemployment. The differences between France and Germany over their respective views of the internal market remain significant.

Once the Charter was placed upon the EU agenda, the lack of a coordination mechanism between the French and Germans quickly led to conflict between the two. When the French took over the presidency of the Council in the second half of 1989, Mitterrand signaled that completion of the Social Charter would be a key goal. It quickly became clear, though, that a binding Social Charter would not be possible by the end of the French tenure in the presidency. Rather than wait and build up support for a binding agreement, as the Germans were suggesting, ${ }^{9}$ President Mitterrand chose to push forward. Official German reaction was muted, although privately the Germans were quit displeased with the French decision. From the French point of view, signing an admittedly weak document demonstrated French resolve to get ahead on social policy. Additionally, even a non-binding Social Charter would be an addition to the French cache of Council regulations, underscoring France's influence in European politics. The German government, however, was unsatisfied with largely symbolic gestures, and immediately proposed a series of steps to implement the Charter (BAS 1990, 7-8). This was followed by a Commission Action Programme (Commission of the EC 1989).

There is little evidence, then, to support an interpretation of the development of EU social policy which underscores Franco-German policy coordination. Why is it that Franco-German cooperation failed to develop in this policy area? Unfortunately coalition theory, and specifically the FrancoGerman cooperation hypothesis, fail to offer explanations. One potential source of explanation is domestic politics; unfortunately, intergovernmental approaches such as the Franco-German hypothesis assume away domestic politics. 


\section{Explaining the Failure of the Franco-German Alliance}

One way to understand why Franco-German policy coordination failed to develop in this field is to examine the domestic contexts within which both governments operated. I have developed this argument elsewhere (1993), and shall only outline the argument here.

Within each state, political pressures were quite different. Outside of official circles, there was little effort in France to push for the adoption of a more rigorous European social program. With over half of organized labor (the CGT) ideologically opposed to French membership in the EU, and in the context of relatively low union membership in France (see Table 3), the socialist government was virtually alone in calling for a balance between social and economic accomplishments in the EU. The differences in effectiveness in lobbying on the part of capital and labor in both cases can be explained by examining their respective institutional ties with the state.

The organization of labor and capital in France and Germany is quite different. Unlike Germany, where most trade unions are organized in a central organ representing the political interests of labor, French trade unions are split along political lines (Lecher 1989, 173-75). The largest union, the Confédération Général du Travail (CGT) is dominated by orthodox Marxist thinking, and largely refuses to work with the government on EU matters (Klein 1989, 91-4). Its requests for membership in the ETUC have been repeatedly blocked by other members, in particular by the French socialist/social democratic union Force Ouvriére (FO). FO has threatened to quit the ETUC if the CGT is allowed to join (Die Mitbestimmung 1988). Additionally, the French unions weakened significantly during the economic crises of the 1970s and 1980s. Membership dropped, government reforms designed to introduce work-place democracy backfired (Brown 1991), and the French government, shifting from relatively managed to relatively free market thinking in mid-decade, passed laws to increase flexibility in the work force. The major French push for completing the internal market came from business, which had little interest in a social dimension to the SEA. In both Germany and France, business interests are highly organized. Regardless, there are differences in their effectiveness. German neo-corporatism, coalition governments, and German federalism require the state to attempt to balance the interests of capital and labor (Katzenstein 1987), more fully than in France. Further, the representation of German business interests in UNICE is split between the Federation of German Industry (BDI) and the Federation of German Employers' Associations (BDA), a division which is said to be confusing to the French. ${ }^{10}$ As a result, French support for EU social policy comes largely from a generally unified business and the party 
in power, in the case of the Social Charter, a Socialist government which had been engaged for most of the last decade in less-than-socialist economic policies. German support, in contrast, comes from compromises worked out among capital, labor, and the state, with German business representation in the EU organizationally divided. ${ }^{11}$

It is difficult to determine the precise reasons President Mitterrand supported a social dimension to the 1992 program, but several seem likely. First is an attempt to protect the relatively progressive French social system from social dumping, particularly vis-à-vis the southern European states. By this argument, the Hoover case cited above might be interpreted as the first shot in a social dumping "war." At the same time, the French government has been unwilling to expand its social legislation to encompass Germanstyle codetermination, pushing instead for greater work force flexibility. Additionally, French governments have traditionally favored strengthening EU social policy, in part to attract voters. Finally, French leadership ends are served if an EU social policy is developed, since the French have long been pushing for EU competence in this policy area.

An EU Social Charter was supported by the French state and the politically weak unions (except the CGT). French business interests were opposed to a mandatory charter, but supported market-oriented and nonbinding provisions. Hence, when bargaining became difficult, the French government found that compromise was unhindered by domestic political forces.

In Germany, the social implications of the SEA were fiercely debated by the unions and business. This debate necessitated government intervention to coordinate a common German position. German trade unionists have been criticized for reacting slowly to the SEA, but when they did act, they did so with some effect. All wings of the trade union movement issued analyses of the SEA, running the full range of degrees of negativity, from slightly to very (Breit 1988, 1989; Steinkühler 1989; Siebert 1989a, 1989b). The German Dachverbände for labor and capital, the DGB, BDI, and BDA, disagreed on the need for social policy harmonization. From the DGB's point of view, completion of the internal market would be politically possible only when the social dimension of the EU was also developed (DGB 1992). German business, like its French counterpart, supported non-binding minimum standards for EU social policy, but rejected DGB calls for qualitative equalization of social conditions in Europe (Adamy 1989, 554-55). The BDI even called for competition among European social systems, a clear signal to the unions that German business would not support union positions on European social issues. The BDA, the employers association which, in the German scheme, is responsible for coordinating the business side of 
social policy and wage bargaining, rejected DGB demands for tight European works councils regulations.

The DGB and the BDA issued a joint statement on EU social policy and the Social Charter in July 1989 (BAS 1989, 46), yet strong differences of opinion continued between the leaders of Germany industry and the unions. A key issue was German support for EU-wide company law, in particular the realization of codetermination in EU firms. The unions insisted that efforts should be made to encourage codetermination, first in firms operating across borders in Europe. This was seen by capital and the Kohl government to be unrealistic, although Kohl supported protection of German codetermination laws. Business also supported codetermination, although the unions complained that capital was not very committed to German codetermination, and feared that re-opening the debate at the EU level might be used by business to weaken German legislation. ${ }^{12}$

The federal government sought compromise between capital and labor. Chancellor Kohl called for the maintenance of differences in social standards if necessary, to avoid lowest-common-denominator solutions. He also pushed European social policy during the Germany Council presidency during the second half of 1988 (Handelsblatt 1988; Frankfurter Rundschau 1988). During the second national conference over EU policy in Bonn in August 1989, Kohl pressured capital and labor to develop common positions on EU matters, especially the European-wide adoption of German-style codetermination (Süddeutsche Zeitung 1989). He sided with the unions against business in support of binding minimum social standards in the Social Charter, but was still criticized by the unions for failing to specifically support key union demands (The Financial Times 1989).

The structure of domestic political forces in both countries is such that French support for expansion of European social policy comes primarily from the state, with the relatively weak and divided unions unable to balance the traditionally strong capital-state relationship in France. This made it easier for the government to accept a non-binding charter, particularly as the state wanted progress, if symbolic, on social affairs while it held the Council presidency. In Germany, in contrast, the state is much more dependent upon cooperation between capital and labor, and it felt committed to support union demands for a stronger document. The dissimilarities in historical, institutional, and legal structures, and political and linguistic factors inhibit close policy coordination between the French and Germans. These difficulties contributed to disagreements between the French and Germans over the content and character of the Charter of Fundamental Social Rights. 


\section{Maastricht and Beyond}

The 1989 Social Charter pleased few of the participants in its negotiation. The British, on the one hand, feared a return to the issue in the future. Outside of Mrs. Thatcher and the minority of Euro-skeptics in her party, few Conservative MPs favored the can of worms (normally called "multispeed Europe") that the precedent-setting British opt-out had opened. The opposition parties hoped to win votes by drawing attention to the government's clear turn away from British workers. The Germans pushed for the EU's implementation plan, without success. The French government largely supported the German initiative. Yet for much of the period between the signing of the Social Charter in December 1989 until the coming into force of the Maastricht treaty revisions in November 1993, most of the social policy agenda failed to move out of the Council of Ministers.

Symbolic of the impasse was the controversy over codetermination, a key element of the economic democracy goals of Jacques Delors. As Table 4 indicates, worker representation regulations vary significantly across Europe. The EU's proposals regarding codetermination have evolved significantly in the past decade, due to pressures placed upon it by the member governments, trade unions, and business. A number of proposals have been offered and rejected, including harmonization up to the highest standards (German and Dutch, for the most part), and a system of three different models of worker representation (which would have effectively institutionalized the existing differences across Europe). In June of 1994, a proposal was adopted which allows the imposition of works councils if management and labor are unable to negotiate an arrangement. This regulation, however, only applies to large firms which draw a significant share of their turnover from operations in other members. Additionally, the powers of these new works councils are very limited, especially in comparison to works councils in many northern European states (excluding France)..$^{13}$ Like EU policies in many other areas, states are allowed to maintain higher social standards than those set by EU legislation. Thus, national policy differences still cause distortions in the internal market, and social dumping remains a political issue.

A key element of the negotiations over the Maastricht treaty revisions was the legal expansion of EU competence into the social field. This provision was pushed very heavily by the Germans and French, and formed an integral part of the complex web of side-payments and pay-offs that constitutes the Maastricht accords. Yet the British remained outside the Social Charter, or so they thought. While the Major government successfully negotiated a social policy opt-out, it has been less successful in 
avoiding the works councils legislation. At this writing, British firms meeting the requirements of the legislation will be subject to it. On the other hand, the British are currently close to securing a weakening of the 1977 European Acquired Rights Directive, which covers worker rights when firms change ownership. France, Italy, and most recently Germany have all agreed with the British that the directive should not apply to privatized public firms.

The prospects for closer Franco-German relations in the social field post-Maastricht are unclear. The inter-ministerial contacts remain underdeveloped. The recent German attention on flexibility in employment law follows-temporally, but not substantively-French reforms of the late 1980s. The French unwillingness to take sides in the dispute between the Commission and the Germans over these proposals, however, suggests some French ambivalence. The French government's unwillingness to commit itself to the recently completed Franco-German study of European labor markets, presented at their May 1994 summit, is further evidence of differences of interest between the two. It would seem that the conservative government and the Socialist president differ-in unexpected ways-on EU social policy.

\section{Conclusion: Implications for Integration Theory}

Franco-German policy coordination is not very evident in European social policy, particularly in the case of the European Social Charter. PostSocial Charter and post-Maastricht developments indicate that policy coordination remains incomplete. As a result of domestic political and institutional constraints, bilateral contacts in the development of European social policy are just beginning. These constraints, of course, have been overcome in the past in some policy areas, most notably military cooperation. Regardless, one should not assume that domestic political and institutional constraints to cooperation can be ignored, particularly in light of the intergovernmental constraints upon coordination noted above.

There are several implications of this finding for integration theory. First, it is important to distinguish between the broad policy statements emanating from summits between Chancellor Kohl and President Mitterrand, and the bargaining and voting behavior of the two governments in the Council of Ministers. With their meeting in Mulhouse in May 1994, French and German heads of government have met in Franco-German summits a total of 53 times. Yet, not unexpectedly, significant differences of interest remain between the two. Additionally, translating broad political support for EU 
policy proposals into specific legislation remains difficult for the two governments.

Second, it may be that the Franco-German relationship is changing in character and importance. To the extent to which qualified majority rules are applied in the EU (as they were not in the case of the Social Charter), neither the Germans nor the French may be as dependent upon the other as they were under unanimity rules. At the same time, it is important to remember that unanimity principles still influence votes taken under qualified majority rules. States still try to avoid isolating each other. Regardless, such institutional changes as qualified majority voting open the possibility of floating coalitions in EU decision making, lessening the importance for close Franco-German policy coordination.

Additionally, as the British increasingly seek to influence EU outcomes, the long-standing close policy coordination among the Germans and French may prove less necessary than before. Some have begun to speak of a British-French-German axis. As scholars in the 1970s and 1980s often spoke of the US "playing the China card" in its relations with the Soviet Union, so too might the French play a "British" card against the Germans, and viceversa. These data suggest not only that the focus of bargaining shifted in the development of the Social Charter, but also that institutional and political constraints limited Franco-German cooperation in the social field. In some areas, German positions are closer to the free market-oriented British than they are to the French. Clearly, we must be careful not to draw too much from the numerous Franco-German summits.

Franco-German relations over social policy must clearly be put in the larger context of relations between the two. The Euro-Corps, for example, and its parade through Paris this past summer, demonstrates that the relationship between the two is broad and politically significant. Yet such developments should not be seen as heralding the end of conflicts of interest between the two.

A good test of the Franco-German relationship will be found in the coordination of German and French leadership between July 1994 and July 1995, when first the Germans and then the French hold the EU presidency. The capacity of the two to coordinate their respective tenures in the presidency will be largely determined not by summits between heads of governments, but by their ability to develop detailed and specific policy proposals that sway the minds of the other member governments. This study finds that development of these policy proposals will be shaped by the character of inter-ministerial contacts between France and Germany.

In sum, models of regional integration that rest upon coalition building and, specifically, the Franco-German coalition, remain problematic explana- 
tions of EU policy-making processes. As the case presented here suggests, domestic politics plays a much more significant role in EU policy outcomes than coalition building. Indeed, the coalition argument must, ultimately, rest upon some understanding of domestic politics. Our models of regional integration will be improved only when we incorporate, in a systematic fashion, our understanding of domestics politics and its links to interstate behavior.

\section{NOTES}

An earlier version of this paper was given at the conference "The Franco-German Partnership and the European Project", Northwestern University, 4-5 May 1991. Thanks to Gerhard Fuchs. The author would also like to thank the anonymous reviewers of the American Review of Politics.

${ }^{1}$ With the ratification of the Maastricht treaty revisions in November, 1993, the European Union was created, which organizationally speaking subsumes the European Community (EC). Yet the usage remains controversial, even among the institutions of Europe. I choose to use European Union here, except when referring to documents produced before November, 1993.

${ }^{2}$ During the summer of 1994 , the Council, responding to a suit brought by the British newspaper The Financial Times, began to publish the results of its votes.

${ }^{3}$ This institutional and political state of affairs also leads to vague and unclear legislation, another EU problem.

${ }^{4}$ These provisions have recently come under criticism in the German government, as it struggles to find the economic resources needed to speed east German reconstruction.

${ }^{5}$ Anecdotal evidence of these problems can be found in the fears raised by Spanish union leaders, who while expressing concern for the effects of completion of the internal market for all European trade unions, are so occupied with domestic problems that they have little time to press for raising Spanish work standards to those of other European states (The Financial Times 1989).

${ }^{6}$ Binding provisions included freedom of movement for workers, social security for migrant workers, freedom of establishment for self-employed persons, equal pay for male and female workers, and the establishment of a Social Fund. Non-binding provisions of the Treaty of Rome in the area of social policy included paid holiday schemes, common vocational training programs, and some general provisions concerning standards of living and working conditions (Venturini 1988).

${ }^{7}$ With the accession of Greece, Spain, and Portugal, common social policy has been even more difficult to develop, as these states tend to have less-developed social programs than do the other members. Additionally, underdevelopment considerations restrict the political room for maneuver in these states.

${ }^{8}$ Most of the following is based upon the author's interviews in Bonn, March and April, 1991.

${ }^{9}$ Author's interviews in Bonn, March and April, 1991.

${ }^{10}$ Author's interviews in Bonn, March and April, 1991. 


\begin{abstract}
${ }^{11}$ There is, of course, close policy coordination in UNICE between the BDI and BDA.

${ }^{12}$ Attempts by German firms to avoid parity codetermination in the steel industry contributed to a break-down in national tripartite negotiations in Germany in 1976. The BDI's calls for competition among European social programs raised similar fears in the minds of some unionists that German capital was ready to manipulate EU law to weaken domestic work law. See Adamy 1989.

${ }^{13}$ Like EU policies in many other areas, states are allowed to maintain higher social standards than those set by EU legislation.
\end{abstract}

\title{
REFERENCES
}

Adamy, W. 1989. Soziale Grundrechte in der Europäischen Gemeinschaft. WSI Mitteilungen. 42.

BAS (Bundesministerium für Arbeit und Sozialordung). 1989. Der EG-Binnenmarkt und die Sozialpolitik. Bonn.

. 1990. Vorschläge der Bundesregierung für Soziale Mindeststandards. Der EGBinnenmarkt und die Sozialpolitik. Volume 2.

BDA (Bundesvereinigung der Deutschen Arbeitgeberverbände). 1989. Stellunghahme zur Sozialen Dimension des EG-Binnenmarktes. Eurolnfo No. 4, 16 February.

Berie, Herman. 1989. Erfolg für den europäischen Sozialraum. In Bundesministerium für Arbeit und Sozialordung, Der EG-Binnenmarkt und die Sozialpolitik. Bonn.

Breit, Ernst, ed. 1988. Europäischer Binnenmart: Wirtschafts-oder Sozialraum. Bonn: Europa Union Verlag.

. 1989. Für ein Soziales Europa. Köln: Bund Verlag.

Breit, Ernst, and K. Murmann. 1989. Gemeinsame Erklärung von DGB und BDA. In Bundesministerium für Arbeit und Sozialordung. Der EG-Binnenmarkt und die Sozialpolitik. Bonn.

Brown, B.E. 1991. The Rise and Fall of Autogestion in France. Pp. 195-214 in Donald Hancock, John Logue, and Bernt Schiller, eds. Managing Modern Capitalism: Industrial Renewal and Workplace Democracy in the United States and Western Europe. New York: Praeger.

Cameron, David R. 1992. The 1992 Initiative: Causes and Consequences. Pp. 23-74 in Alberta M. Sbragia, ed. Euro-Politics: Institutions and Policymaking in the "New" European Community. Washington, DC: The Brookings Institution.

Commission of the European Communities. 1988a. The Social Dimension of the Internal Market. Social Europe. Brussels. cation.

1988b. The Social Dimension of the Internal Market. Commission Communi-

1989. Action Programme for the Implementation of the EC Social Charter. COM (89) 568, 29 November.

Council of the European Communities. 1989. Community Charter of Basic Social Rights of Workers. 10928/89, SOC 467, 19 December.

DGB (Deutscher Gewerkschaftsbund). 1992. Europas Wirtschaft 1992. Düsseldorf. 
ETUC (European Trade Union Confederation). 1985a. EC Commission's Programme and the Brussels European Council. ETUC Statement. 29-30 March.

. 1985b. The EEC at the Crossroads. ETUC Statement to the European Council in Milan, 28-29 June.

1985c. ETUC Statement on the Internal Market. October.

1985d. Internal Market and the European Social Dimension. 12-13 December. . 1987a. Delores Plan: Making a Success of the Single Act-A New Frontier for Europe, Statement of the Executive Committee of the ETUC, 23-24 April.

. 1987b. Statement on the European Council Session, ETUC Executive Committee, December.

. 1988. Creating the European Social Dimension in the Internal Market: European Social Programme. 11-12 February.

The Financial Times. 1989. Kohl Backs Unions on EC Social Charter. 1 September.

Frankfurter Rundschau. 1988. Kohl Wirbt für Soziales Europa. 28 June.

Garrett, Geoffrey. 1992. International Cooperation and Institutional Choice: The European Community's Internal Market. International Organization 46:533-60.

Haas, Ernst. 1975. The Obsolescence of Regional Integration Theory, Research Series No. 25. Institute of International Studies. Berkeley, CA: University of California.

Handelsblatt. 1988. In Straßburg Wird für einen Europäischen Sozialraum plädiert. 7 July.

Huelshoff, Michael G. 1993. European Integration After the SEA: The Case of the Social Charter. Political Research Quarterly 46:619-640.

. 1994. Domestic Politics and Dynamic Issue Linkage: A Reformulation of Integration Theory. International Studies Quarterly 38:255-279.

Huelshoff, Michael G., and Thomas Pfeiffer. 1991/92. Environmental Policy-Making in the EC: Neo-Functionalist Sovereignty Transfer or Neo-Realist Gate-Keeping? International Journal 47:136-158.

Katzenstein, Peter. 1987. Politics and Policy in West Germany: The Growth of a SemiSovereign State. Philadelphia: Temple University Press.

Keohane, Robert O., and Joseph S. Nye. 1977. Power and Interdependence: World Politics in Transition. Boston: Little, Brown.

Klein, Albert. 1989. Die CGT und die Westeuropäische Integration. In G. Siebert, ed., Wenn der Binnenmarkt Kommt.... Frankfurt aM: Nachrichten-Verlag, 91-94.

Laffan, B. 1983. Policy Implementation in the European Community: The European Social Fund as a Case Study. Journal of Common Market Studies 21:389-408.

Lecher, W. 1989. Zur Lage der Gewerkschaften in Europa. In Franz Steinkühler, ed., Europa '92: Industriestandort oder Sozialer Lebensraum. Hamburg: VSA Verlag. Mayer, Otto. 1989. Zur Sozialen Dimension des Europäischen Binnenmarktes. In Otto Mayer, H. Scharrer, and H. Schmal, eds., Europäische Binnenmarkt: Perspektiven und Probleme. Hamburg: Verlag Weltarchiv GmbH. 341-378.

Die Mitbestimmung. 1988. Ohne Gewerkschaftliche Einheit Sind die Arbeitnehmer Schwach. November. 620-622.

Moravcsik, Andrew. 1991. Negotiating the Single European Act. Pp. 41-84 in Robert O. Keohane and Stanley Hoffmann, eds., The New European Community: Decisionmaking and Institutional Change. Boulder, CO: Westview.

1993. Preferences and Power in the European Community: A Liberal Intergovernmentalist Approach. Journal of Common Market Studies 31:473-524. 
Mosley, H. 1990. The Social Dimension of European Integration. International Labour Review 129: 147-64.

Muhr, G. 1990. 1992. The Social Aspects. Labour and Society 15:1-11.

Nugent, Neill. 1991. The Government and Politics of the European Community, 2nd ed. Durham: Duke University Press.

Reich, Simon. 1990. The Fruits of Fascism: Postwar Prosperity in Historical Perspective. Ithaca: Cornell University Press.

Sandholtz, Wayne, and John Zysman. 1989. 1992: Recasting the European Bargain. World Politics 42:95-128.

Siebert, G. ed. 1989a. Europa 92: EG-Binnenmarkt und Gewerkschaften. Frankfurt: Nachrichten Verlag. Verlag.

Simmonian, Haig. 1985. The Privileged Partnership: Franco-German Relations in the European Community 1969-1984. Oxford: Clarendon Press.

Steinkühler, Franz, ed. 1989. Europa '92: Industriestandort oder Sozialer Lebensraum. Hamburg: VSA-Verlag.

Süddeutsche Zeitung. 1989. Deutscher Sozialstandard für die EG Abgelehnt. 31 August. Taylor, Paul. 1983. The Limits of European Integration. London: Croom Helm. . 1989. The New Dynamics of EC Integration in the 1980s. In Juliet Lodge, ed., The European Community and the Challenge of the Future. New York: St. Martins.

Tranholm-Mikkelsen, Jeppe. 1991. Neo-Functionalism: Obstinate or Obsolete? A Reappraisal in the Light of the New Dynamism of the EC. Millennium 20:1-22.

Tyszkiewicz, Z. 1989. European Social Policy-Striking the Right Balance. European Affairs 3:70-75.

Venturini, Paul. 1988. 1992: The European Social Dimension. Brussels: Commission of the European Communities.

Wallace, Helen. 1985. Negotiations and Coalition Formation in the European Community. Government and Opposition 20:453-472.

1986. The Conduct of Bilateral Relationships by Governments. In R. Morgan and C. Bray, eds., Partners and Rivals in Western Europe. Aldershot: Gower. 